\title{
Analysis of apoptosis and expression of bcl-2 gene family members in the human and baboon ovary
}

\author{
Koji Kugu ${ }^{1}$, Valerie S. Ratts ${ }^{2}$, Gary N. Piquette ${ }^{3}$, Kim I. Tilly ${ }^{1}$, \\ Xiao-Jing Tao', Stephanie Martimbeau', \\ Graham W. Aberdeen ${ }^{4}$, Stanislaw Krajewski ${ }^{5}$, John C. Reed ${ }^{5}$, \\ Gerald J. Pepe ${ }^{6}$, Eugene D. Albrecht ${ }^{4}$ and Jonathan L. Tilly ${ }^{1,7}$ \\ 1 Vincent Center for Reproductive Biology, Department of OB/GYN, \\ Massachusetts General Hospital/Harvard Medical School, Boston, \\ Massachusetts 02114 USA \\ 2 Department of OB/GYN, Washington University School of Medicine, St. Louis, \\ Missouri 63110 USA \\ ${ }^{3}$ Department of OB/GYN, UCLA School of Medicine, Los Angeles, California \\ 90048 USA \\ ${ }^{4}$ Department of OB/GYN, University of Maryland School of Medicine, Baltimore, \\ Maryland 21201 USA \\ 5 The Burnham Institute, La Jolla, California 92037 USA \\ ${ }^{6}$ Department of Physiology, Eastern Virginia Medical School, Norfolk, Virginia \\ 23501 USA \\ 7 corresponding author: Jonathan L. Tilly, Ph.D., Massachusetts General \\ Hospital, VBK137E-GYN, 55 Fruit Street, Boston, Massachusetts 02114 USA. \\ tel: +617 724 2182; fax: +617 726 7548; \\ email: tilly.jonathan@mgh.harvard.edu
}

Received 8.5.97; revised 16.7.97; accepted 17.8.97

Edited by D. Green

\begin{abstract}
Recent data support a role for apoptosis, under tight regulatory control by bcl-2, oxidative stress response, tumor suppressor, and CASP gene family members, in mediating granulosa cell demise during follicular atresia in the rodent and avian ovary. Herein we evaluated the occurrence of apoptosis in the human and baboon ovary relative to follicular health status, and analyzed expression of several cell death genes in these tissues. In situ localization of DNA strand breaks in fixed human and baboon ovarian tissue sections indicated that apoptosis was essentially restricted to granulosa cells of atretic antral follicles. Biochemical analysis of DNA oligonucleosomes in individual follicles isolated from baboon ovaries during the ovulatory phase revealed the presence of apoptotic DNA fragments in subordinate but not dominant follicles, thus substantiating the in situ labeling studies. Messenger RNA transcripts encoded by the bax death susceptibility gene, the $b c l-x_{\text {long }}$ survival gene, the $b c l-x_{\text {short }}$ pro-apoptosis gene, the p53 tumor suppressor gene, and two members of the CASP gene family (CASP-2/lch-1, CASP-3/ CPP32), were detected by Northern blot analysis of total RNA prepared either from human ovaries or from Percoll-purified granulosa-lutein cells obtained from patients undergoing assisted reproductive technologies. Lastly, immunohistochemical localization of the BAX death-susceptibility protein in the human ovary revealed abundant expression in granulosa cells of early atretic follicles, whereas BAX protein
\end{abstract}

was extremely low or non-detectable in healthy or grosslyatretic follicles. We conclude that apoptosis occurs during, and is probably responsible for, folicular atresia in the human and baboon ovary. Moreover, apoptosis in the human ovary is likely controlled by altered expression of the same cohort of cell death regulatory factors recently implicated as primary determinants of apoptosis induction or suppression in the rodent ovary.

Keywords: apoptosis; BCL-2; BCL-X; BAX; p53; caspase; $\mathrm{ICH}-1$; CPP32; atresia; granulosa cell; ovary

Abbreviations: $\mathrm{BAX}, \mathrm{BCL}-2$-associated X-protein; BCL-2, Bcell lymphoma/leukemia-2 protein; BCL-X, BCL-2-related protein-X; caspase, cysteine aspartic acid-specific protease (CASP, designation of the gene); CPP32, cysteine protease p32 (caspase-3); ddATP, dideoxy-ATP; GLC, granulosa-lutein cell; ICE, interleukin-1 $\beta$-converting enzyme (caspase-1); ICH1, ICE/CED-3 homolog-1 (caspase-2); zVAD-FMK, benzyloxycarbonyl-Val-Ala-Asp-fluoromethylketone; zDEVD-FMK, benzyloxycarbonyl-Asp-Glu-Val-Asp-fluoromethylketone

\section{Introduction}

Using sensitive biochemical and molecular biological analyses, the occurrence of apoptosis in female germ cells, follicular granulosa cells, and luteal cells during ovarian development and cyclic function in laboratory and domestic animal species has been established (reviewed in Tilly, 1996; Martimbeau and Tilly, 1997). Moreover, identification of apoptosis as the underlying mechanism responsible for controlled cellular deletion in the ovary has sparked numerous investigations into the intracellular effector pathways that are either activated or repressed during execution of the cell death command. Consistent with a solid foundation of research data derived from analysis of apoptosis regulation in non-gonadal tissues and tumor cell lines (reviewed in Stellar, 1995; Wyllie, 1995; Ko and Prives, 1996; Reed et al, 1996; Yang and Korsmeyer, 1996; Patel et al, 1996; Kumar and Lavin, 1996), recent reports have documented the possibility that a highlyconserved pathway of cell death modulators plays a prominent role in determining cell fate in the ovary (reviewed in Tilly, 1996; Tilly et al, 1997). For instance, proteins encoded by members of the $b c l-2$ gene family, including both positive (BAX, BCL- $\left.X_{\text {short }}\right)$ and negative (BCL-2, BCL- $X_{\text {long }}$ ) regulators of apoptosis (reviewed in Reed et al, 1996; Yang and Korsmeyer, 1996), have been proposed as key mediators in the control of cell death in the rodent, avian and bovine ovary (Knudson et al, 1995; Ratts et al, 1995; Tilly et al, 1995a; Johnson et al, 1996, 1997; Rueda et al, 1997; reviewed in Tilly et al, 1997). Along 
these lines, nuclear accumulation of the p53 tumor suppressor protein, a transcriptional regulator of the $b c l-2$ and bax genes (Miyashita et al, 1994; Miyashita and Reed, 1995), has also been demonstrated in rat granulosa cells destined for apoptosis (Tilly et al, 1995b). Despite the current lack of data formally linking p53 to altered expression of target cell death genes in the ovary, forced expression of p53 in rat granulosa cells does in fact lead to rapid apoptosis (Keren-Tal et al, 1995).

Other effectors not directly related to the BCL-2 family have also been proposed to regulate apoptosis in granulosa cells of the rodent ovary. For instance, members of the CASP (ced-3/lce) gene family, a cohort of apoptosis-inducing proteases that function at the penultimate stage of cell death committal (Martin and Green, 1995; Kumar and Lavin, 1996; Patel et al, 1996), are believed to participate in granulosa cell death. To date, data have been presented that suggest a role for caspase$2(\mathrm{ICH}-1)$ and caspase-3 (CPP32) in follicular atresia in the rat ovary, albeit the function of caspase-1 (ICE) per se remains uncertain (Flaws et al, 1995). In addition, apoptosis in granulosa cells of mouse ovarian follicles cultured in vitro under serum-free conditions is associated with proteolysis of the caspase substrate, fodrin, and is prevented by the two specific peptide inhibitors of caspases, zVAD-FMK and ZDEVD-FMK (Maravei et al, 1997). Taken collectively, these data have served as the basis for a hypothesis that apoptosis and altered expression of cell death genes are events associated with ovarian cellular deletion in all vertebrate species (Tilly et al, 1997). Consequently, it was our objective to investigate the occurrence of apoptosis in the human and non-human primate (baboon) ovary, and to determine the expression of cell death-associated genes in the human ovary. Furthermore, the spatial distribution of $\mathrm{BAX}$, a protein whose expression is well-correlated with and may be required for apoptosis in granulosa cells of the rodent ovary (Knudson et al, 1995; Tilly et al, 1995a), was assessed in healthy and atretic follicles of the human ovary by immunohistochemical localization.

\section{Results}

\section{Detection of apoptosis in the human and baboon ovary}

To first identify the specific cell types that undergo cell death, in situ localization of DNA strand breaks demonstrated that apoptosis was prevalent in granulosa cells of atretic, but not healthy, follicles in the human and baboon ovary (Figure 1). To substantiate the fact that the DNA fragmentation detected in situ was the result of internucleosomal cleavage associated with apoptotic cell death, genomic DNA was extracted from individual dominant (healthy) and subordinate (atretic) antral follicles dissected from late ovulatory phase baboon ovaries. Autoradiographic analysis of DNA integrity revealed the presence of varying degrees of internucleosomal cleavage in subordinate follicles (Figure 2). In contrast, DNA prepared from dominant follicles of the same ovaries did not exhibit evidence of internucleosomal cleavage (Figure 2).

\section{Isolation of cDNAs for human cell death regulatory genes}

Using the RT-PCR technique, we next obtained full-length $\left(b c l-x_{\text {long }}\right)$ or partial (bax, bases $85-530 ; p 53$, bases $206-$ 730; caspase-1, bases 660-1117; caspase-2, bases 6841110 of the long isoform; caspase-3, bases 311-949) cDNAs from human ovarian RNA. Sequence analysis confirmed $100 \%$ identity to the corresponding sequences of the human cDNAs previously reported (data not shown; see GenBank Accessions Z23115/L20121, L22473, X02469/M60950, M87507, U13021, and U13737, respectively).

\section{Expression of cell death genes in the human ovary and in granulosa-lutein cells (GLC)}

After cloning of the human cDNAs, Northern blot analyses were conducted to determine if these genes were expressed in human ovaries and in Percoll-purified GLC. Autoradiographic analysis of RNA blots hybridized with the various probes revealed the presence of bax, bcl-x, p53, caspase-1, caspase-2 and caspase-3 mRNA transcripts in human ovarian RNA samples collected during the follicular phase of the cycle (Figure 3). Percoll-purified GLC were also found to express all of the genes examined (Figure 4), with the exception of CASP-1 (data not shown). In addition, RT - PCR analysis indicated that purified GLC apparently expressed more of the 'short' form of $b c l-x$ mRNA when compared with the relative levels of $b c /-x_{\text {long }}$ versus $b c l-x_{\text {short }}$ mRNA in total ovarian homogenates (Figure 4).

\section{Immunolocalization of BAX protein in granulosa cells destined for apoptosis}

In the final set of experiments, we evaluated the spatial distribution of the BAX death-susceptibility protein in the human ovary as recent studies have provided convincing proof that bax expression is associated with (Tilly et al, 1995a), and may be required for (Knudson et al, 1995), granulosa cell apoptosis in the rodent ovary (reviewed in Tilly et al, 1997). Intense immunostaining for BAX was detected in granulosa cells of early atretic follicles (Figure 5A,B), although BAX immunostaining was absent in the residual granulosa cells of grossly atretic follicles that displayed high levels of DNA fragmentation (Figure 5C; see Figure 1 for in situ DNA labeling/apoptosis). In early atretic follicles, BAX immunoreactivity was most intense in peri-antral granulosa cells, but was also diffusely expressed throughout the theca-interstitial cell layer (Figure 5A,B). The BAX protein was not detected in granulosa cells of healthy developing antral folicles (Figure $5 D$ ), and was similarly low or absent in interfollicular stromal cells (Figure 5).

\section{Discussion}

Initial studies of rat, avian and porcine ovaries documented a role for apoptotic cell death in the loss of granulosa cells during follicular atresia (Hughes and Gorospe, 1991; Tilly et al, 1991, 1992). The occurrence of apoptosis in granulosa cells appears to be a fundamental event conserved among 

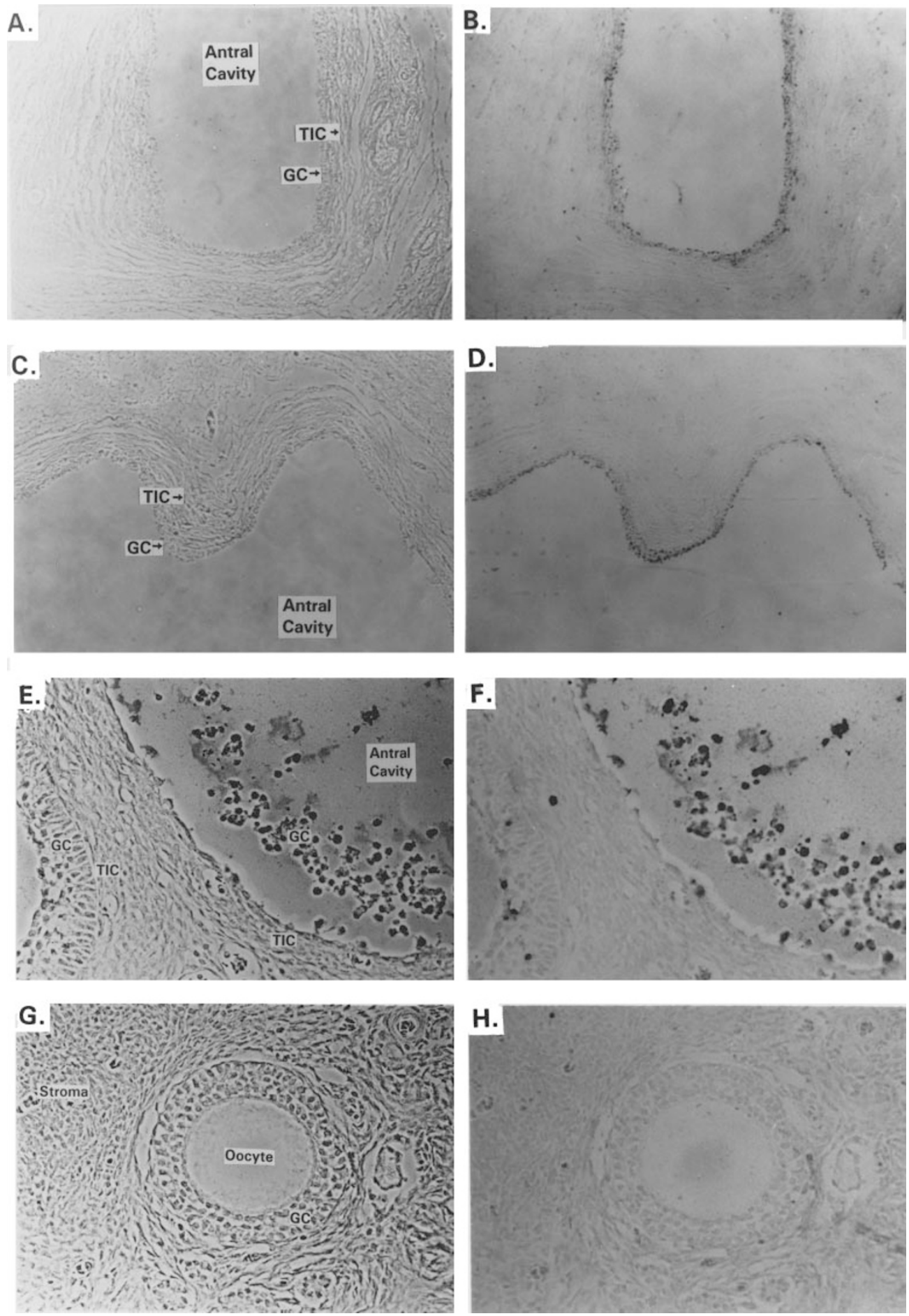

Figure 1 In situ localization of apoptosis-associated DNA strand breaks in granulosa cells of human and baboon ovarian atretic follicles. Panels A-D represent brightfield $(\mathbf{A}, \mathbf{C})$ and phase-contrast $(\mathbf{B}, \mathbf{D})$ photomicrographs of two different grossly-atretic antral follicles in the human ovary (Panel $\mathbf{A}$, approximate follicle diameter $=7-8 \mathrm{~mm}$; Panel C, approximate follicle diameter $=10-12 \mathrm{~mm}$ ). Note the intense labeling of essentially all remaining granulosa cells $(\mathrm{GC})$ for apoptotic DNA breakdown (indicated by the darkly-stained cells in Panels B and D), and the relative absence of DNA labeling in theca-interstitial cells (TIC) and the surrounding interfollicular stroma. These data are representative of results observed with ovaries from five different patients. These findings were confirmed by a similar analysis of ovaries from cycling female baboons (Panels $\mathbf{E}-\mathbf{H}$ ), which also revealed the occurrence of apoptosis in GC of atretic antral follicles (note the darkly-stained cells in Panel F; E, brightfield view of the tissue shown in F by phase-contrast). By comparison, TIC and cells in the surrounding stroma were not labeled. The specificity of the detection of apoptosis by this approach was further shown by the lack of DNA labeling in any cells of a healthy preantral follicle (G,H; brightfield and phase-contrast photomicrographs, respectively) present within the same ovarian section as the antral follicles depicted in Panels E,F. These data are representative of results from analysis of ovaries from four different baboons (see also Tilly, 1993) 


\section{FOLLICLE STATUS}

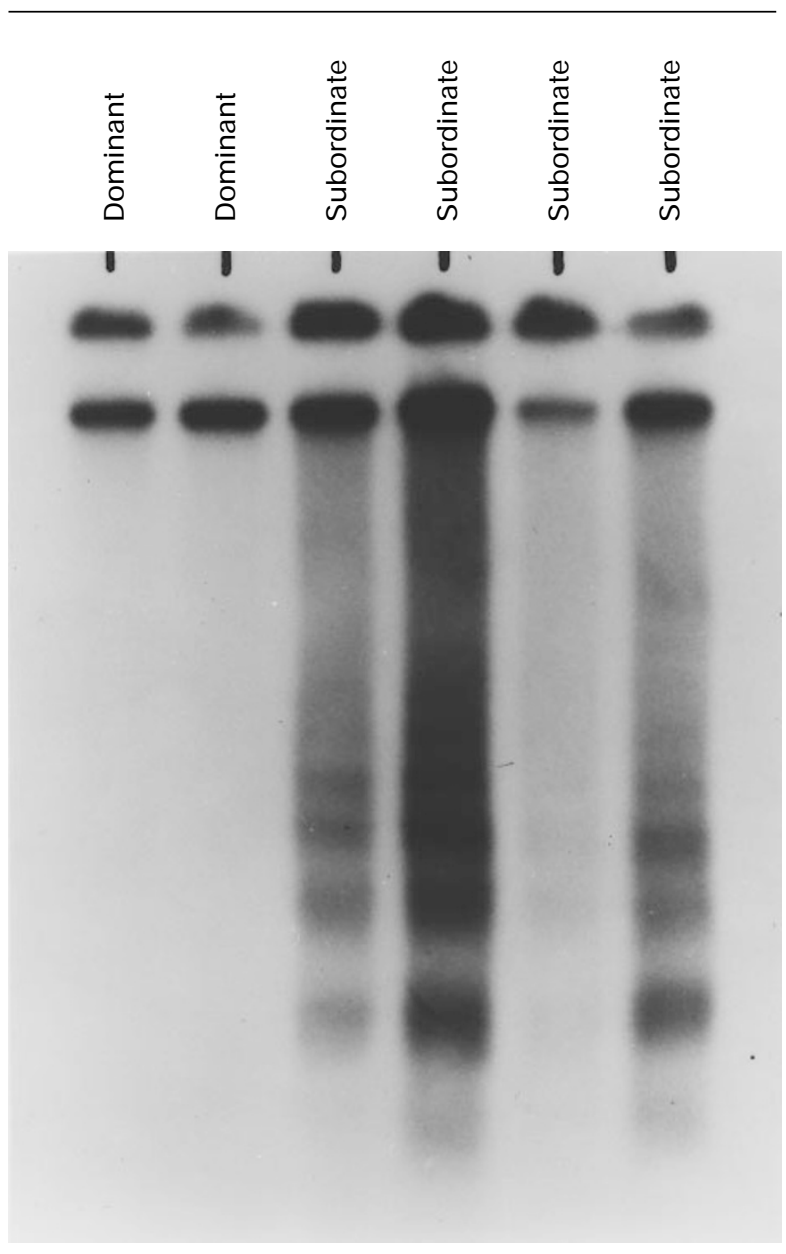

Figure 2 Biochemical analysis of internucleosomal DNA cleavage in extracts of individual follicles isolated from ovulatory phase baboon ovaries. Genomic DNA was extracted from each follicle, radiolabeled with [ $\left.\alpha^{32} P\right]-d d A T P$ using the terminal transferase reaction, and resolved by agarose gel electrophoresis. After drying, gels were exposed to autoradiographic films at $-80^{\circ} \mathrm{C}$ to visualize the absence or presence of oligonucleosomal DNA fragments characteristic of cell death via apoptosis. Data from one dominant follicle $(>10 \mathrm{~mm})$ and two subordinate antral follicles $(4-7 \mathrm{~mm})$ are shown from each of two baboons in the late follicular phase of the cycle

vertebrate animal species as this form of physiological cell death has been identified in atretic follicles of mouse, rabbit, bovine and ovine ovaries as well (Gavrieli et al, 1992; Dharmarajan et al, 1994; Jolly et al, 1994, 1997; Maravei et al, 1997). Despite these advances in our understanding of the mechanisms responsible for ovarian cellular deletion in animal models, comparatively little is known of the occurrence and regulation of physiological cell death in human follicular cells. In this investigation, extensive levels of DNA fragmentation indicative of apoptotic cell death were detected, in situ, in granulosa cells of atretic antral follicles of the human and baboon ovary. These data, which were fully supported by demonstration of oligonucleosomal DNA fragments in individual subordinate but not dominant follicles isolated from baboon ovaries in the ovulatory phase of the cycle, are
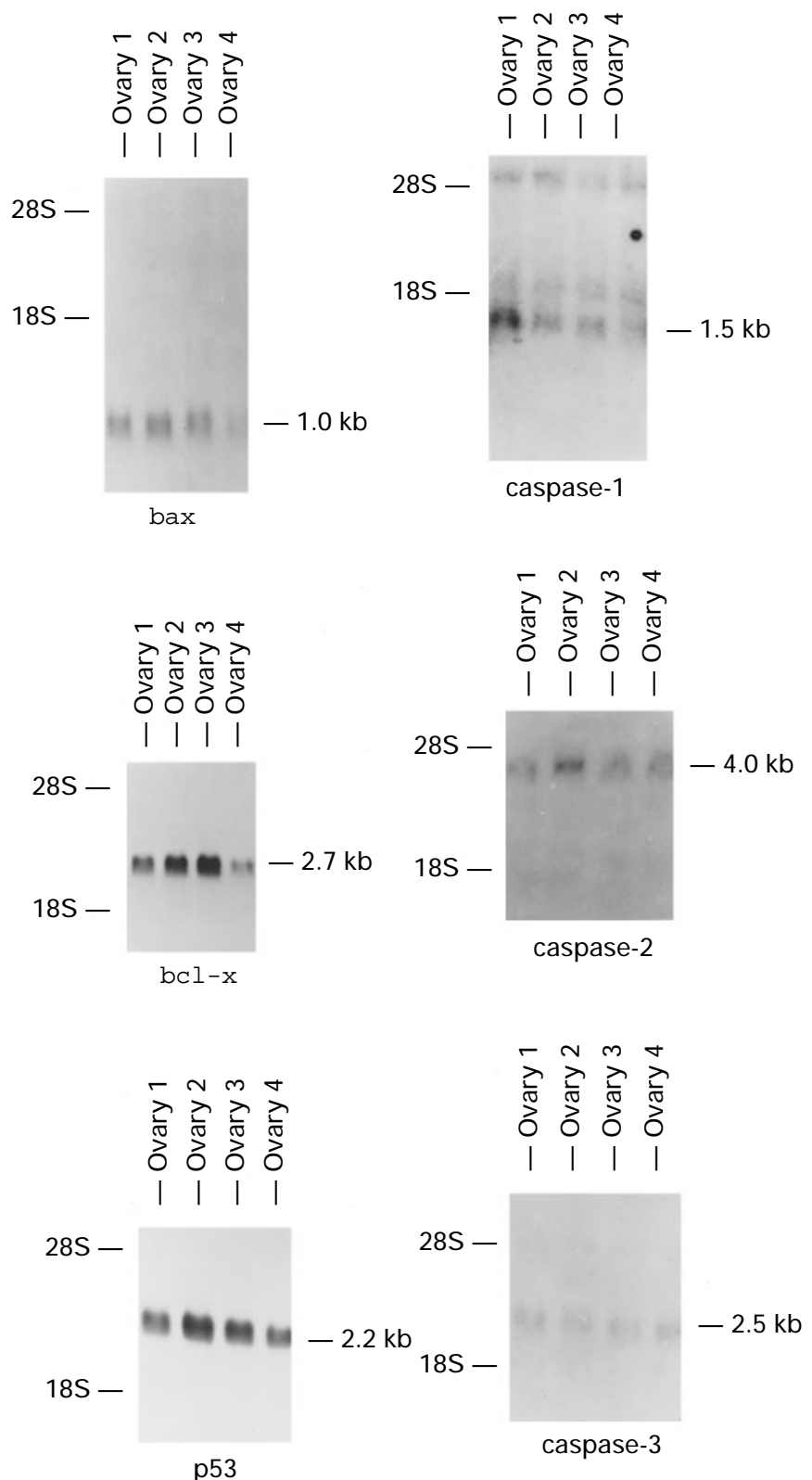

Figure 3 Northern blot analysis of cell death gene expression in the human ovary. Total RNA extracted from ovaries of four different patients (indicated as Ovary 1-4 over each blot) was resolved by denaturing gel electrophoresis $(10 \mu \mathrm{g} /$ lane), blotted to nitrocellulose and hybridized to radiolabeled antisense RNA probes against human bax, bcl- $x, p 53$, caspase-1, caspase- 2 or caspase-3. The estimated size of each primary transcript for each gene studied (in kilobases, $\mathrm{kb}$ ), and the migration distances of the $18 \mathrm{~S}$ and $28 \mathrm{~S}$ rRNA species, are indicated

consistent with the identification of apoptosis in granulosa cells of atretic follicles in all other species examined to date.

Confirming that apoptosis was prevalent in granulosa cells of human atretic follicles, we next pursued investigations into the potential mechanisms involved in activating this physiological death pathway in the human ovary. Recent data derived from studies of apoptosis regulation 

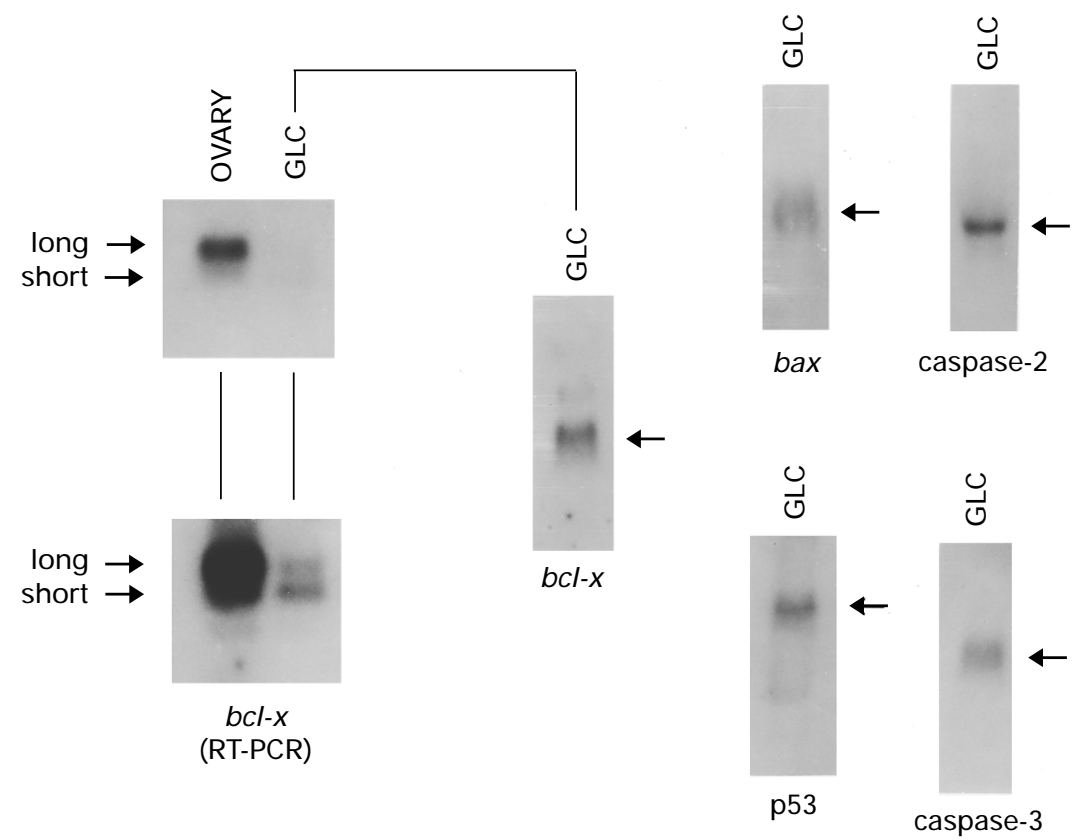

Figure 4 Cell death gene expression in human granulosa-lutein cells (GLC). Total RNA extracted from Percoll-purified GLC was analyzed as described in the legend to Figure 3 for the presence of bax, bcl-x, p53, caspase-1, caspase-2 and caspase-3 mRNA transcripts using radiolabeled antisense RNA probes and Northern blot analysis (arrows indicate the transcripts as defined in Figure 3). Under these conditions, caspase-1 mRNA could not be detected in GLC (data not shown). In addition to the Northern blot analysis of $b c /-x$ mRNA in GLC, the far left panel depicts the results obtained from RT-PCR/Southern blot hybridization analysis of the 'long' versus 'short' forms of the message in total RNA prepared from whole ovary or from GLC. Due to differences in the relative abundance of $b c /-x$ mRNA in the two preparations, two different autoradiographic exposures were required and are presented (upper panel, $6 \mathrm{~h}$; lower panel, $18 \mathrm{~h}$ ). As revealed by RTPCR, note that GLC apparently possess roughly equivalent amounts of the long and short forms of the $b c l-x$ transcript, whereas whole ovary contains primarily the long form. These data are representative of results obtained with ovary and GLC RNA prepared from at least four different patients per transcript analyzed

in the ovary of rodents have revealed that the death of granulosa cells during atresia is likely controlled by the protein products of several recently characterized apoptosis-associated genes. For example, several members of the bcl-2 gene family are expressed in granulosa cells of the rat ovary (Tilly et al, 1995a), and enhanced expression of the bax death-susceptibility gene (Oltvai et al, 1993) has been reported to herald demise of granulosa cells during follicular atresia in vivo and in vitro (Tilly et al, 1995a; Tilly, 1996). The role of BAX in ovarian cell death, implied by data obtained from analysis of changes in bax mRNA levels, has been reinforced following evaluation of mice harboring a targeted disruption in the bax gene. Histologic analysis of ovaries from BAX-deficient mice revealed an apparent defect in the ability of granulosa cells to undergo apoptosis during follicular atresia (Knudson et al, 1995).

Our present findings from the mRNA and protein analyses indicate that expression of the bax gene in the human ovary also predominates in granulosa cell populations that are on the verge of apoptosis, but is absent in granulosa cells of healthy follicles. Furthermore, in the same early atretic follicle we noted discrete immunolabeling of peri-antral granulosa cells without evidence BAX immunostaining in the adjacent granulosa cells lying more proximal to the basal lamina. This apparent 'gradient' of BAX within the follicle mirrors a similar 'gradient' of apoptosis that is known to occur in granulosa cells during atresia of antral follicles (reviewed in Tilly and Ratts, 1996).
Therefore, it is possible that the intense BAX immunoreactivity detected in peri-antral granulosa cells prior to marked morphological changes indicative of pending atresia can be used to demarcate a subordinate follicle destined for degeneration. Interestingly, BAX protein was non-detectable in grossly-atretic follicles, suggesting that once BAX has served to predispose the granulosa cells to apoptosis activation, the protein is lost during completion of the cell death process.

Using Northern blot analysis, we also observed robust expression of the $b c /-x$ gene in human ovarian homogenates as well as in Percoll-purified GLC. Further analysis of the $b c l-x$ messages by RT-PCR and Southern blot hybridization confirmed that, similar to data reported for the rat (Tilly et al, 1995a) and avian (Johnson et al, 1996) ovary, the long or 'death repressor' form of bcl-x (Boise et al, 1993) was the primary transcript expressed in human ovarian homogenates. However, purified human GLC apparently expressed more of the short or 'death inducer' form of $b c l-x$ (Boise et al, 1993) as compared with the levels of this mRNA species detected in whole ovarian preparations by $\mathrm{RT}-\mathrm{PCR} /$ Southern blot hybridization. Although the reason for this is unclear at present, we have recently shown that Percoll-purified GLC obtained from individual follicles of patients undergoing assisted reproductive technologies display variable levels of DNA oligonucleosomes (Piquette et al, 1994). Thus, our previous proposal that cellular reorganization within the dominant 

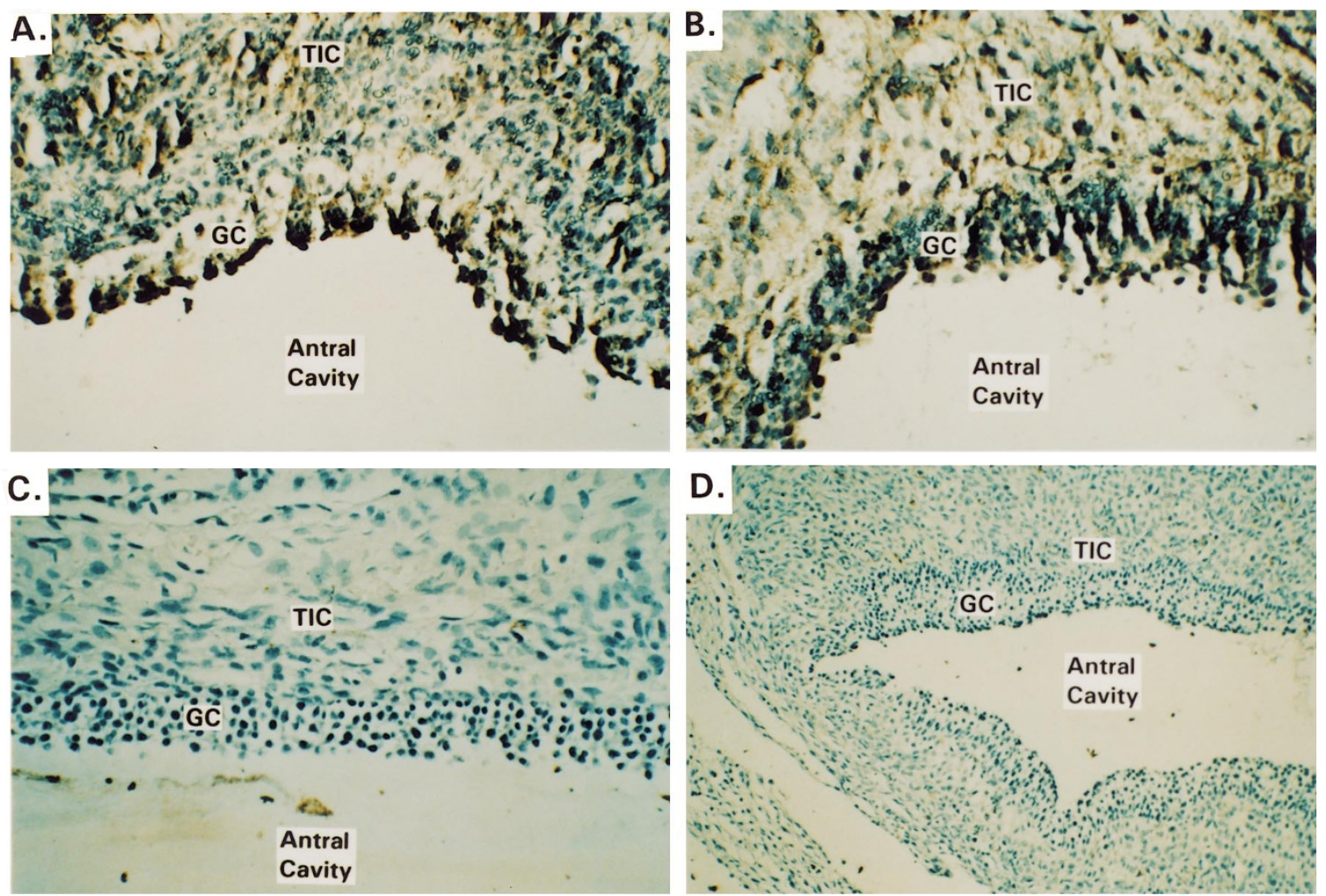

Figure 5 Immunohistochemical localization of the BAX death-susceptibility protein in human ovarian follicles. Panel A depicts an early atretic antral follicle (approximate follicle diameter $=5-7 \mathrm{~mm}$ ) demonstrating BAX immunoreactivity (brown-staining) in theca-interstitial cells (TIC) and in granulosa cells (GC). Note that the most intense BAX immunolabeling is found in the peri-antral GC. This was a consistent observation as shown by a similar pattern of BAX immunoreactivity in a different early atretic antral follicle of approximately the same size (Panel B). In contrast, BAX immunostaining was extremely low or absent in GC and TIC of grossly atretic antral follicles (Panel C; approximate follicle diameter=10-12 mm). The BAX protein was also absent in GC and TIC of healthy antral follicles (Panel D; approximate follicle diamter $=6-8 \mathrm{~mm}$ ). The occurrence of atresia was confirmed by in situ DNA labeling of adjacent sections (see Figure 1 for examples), which revealed that approximately $11 \%, 13 \%,>85 \%$ and $0 \%$ of the granulosa cells were apoptotic in the follicles depicted in Panels $\mathbf{A}$, B, C and $\mathbf{D}$, respectively. These data are representative of results obtained with ovaries from two different patients

follicle prior to, during and after ovulation is associated with apoptosis may be further supported by the findings that a potential death inducer $\left(\mathrm{BCL}-\mathrm{X}_{\text {short }}\right)$ is being upregulated in populations of granulosa cells during follicular rupture and the ensuing luteinization process. Unfortunately, our attempts to document expression of the $b c l-2$ gene in the human ovary or in GLC by RT-PCR analysis proved unsuccessful. It should be noted, however, that previous studies on the presence of this death repressor gene in the human ovary have provided somewhat conflicting data. For example, some investigations failed to detect $b c /-2$ mRNA in human GLC using Northern blot analysis (Jerome F. Strauss III, personal communication), whereas others have reported the presence of $B C L-2$ protein in the human corpus luteum (Rodger et al, 1995) and ovarian stroma (Lu et al, 1993) by immunohistochemistry.

In addition to bcl-2 gene family members, we detected abundant expression of several other cell death regulatory genes in human ovaries and, importantly, in purified human GLC. These included p53, a tumor suppressor protein that may function upstream of BCL-2 family members via transcriptional regulation of the $b c /-2$ and bax genes (Miyashita et al, 1994; Miyashita and Reed, 1995), and caspases, which likely function downstream of BCL-2related proteins in pathways of cell death execution (Chinnaiyan et al, 1996; Estoppey et al, 1997; Perry et al, 1997; reviewed in Kumar, 1997). Interestingly, the levels of caspase-1 mRNA in human ovarian homogenates were extremely low as reflected by the background level of nonspecific hybridization to ribosomal RNA species that had to be maintained in order to visualize the $1.5 \mathrm{~kb}$ caspase- 1 mRNA transcript by Northern blot analysis. Moreover, only caspase-2 and caspase-3 transcripts were detectable in human GLC, even following prolonged autoradiographic exposure of blots hybridized with the caspase-1 cRNA probe. The apparent absence of caspase-1 mRNA in GLC may reflect the lack of involvement of this particular member of the CASP gene family in cell death signaling in this cell type, consistent with data recently reported for the rat ovary (Flaws et al, 1995).

In summary, we have provided evidence supporting the hypothesis that apoptosis and a cohort of conserved celldeath regulatory factors are fundamental to the cyclic growth and regression of ovarian follicles in the human ovary. Additionally, data implicating apoptosis in follicular atresia in the human are supported by parallel experiments 
conducted with baboon ovaries (present studies), as well as a large number of previous studies reported for laboratory and domestic animal models (reviewed in Tilly, 1996). The knowledge gained by such investigations may prove useful for the future design of compounds that would function as contraceptives by selectively destroying target ovarian structures (such as preovulatory follicles for preconception, and the corpus luteum for post-conception) through controlled activation of physiological cell death pathways. Furthermore, a greater understanding of the events involved in mediating germ cell and follicle depletion from the human ovary may lead to novel approaches for delaying the menopause, as well as preventing premature reproductive senescence in females exposed to noxious stimuli such as radio- and chemotherapy and environmental toxicants (reviewed in Tilly and Perez, 1997; Tilly et al, 1997). Our current studies are addressing these hypotheses (Perez et al, 1997), as well as further characterizing the presence and spatial distribution of cell death regulatory proteins in the human female reproductive tract during menstrual cycle-related episodes of apoptosis (Tao et al, 1997).

\section{Materials and Methods}

\section{Tissue samples}

Human ovaries Ovarian tissues were collected from a total of five women between the ages of 32-43 undergoing oophorectomy and/or total abdominal hysterectomy for benign conditions. Wedges were cut from ovaries and either fixed immediately in $4 \%$ neutral-buffered paraformaldehyde (w:v in $1 \times$-concentrated Dulbecco's phosphatebuffered saline, D-PBS) for future histochemical manipulations, or were snap-frozen and stored at $-80^{\circ} \mathrm{C}$ until processed for RNA extraction and analysis.

Human granulosa-lutein cells (GLC) Women between the ages of 22-40, undergoing assisted reproductive technological procedures with controlled ovarian hyperstimulation ( $n=10$ patients), were treated with leuprolide acetate (Lupron; TAP Pharmaceuticals Inc., Deerfield, IL, USA) starting in the mid-luteal phase. On day 3 of the following cycle, patients were treated daily with human menopausal gonadotropins (Pergonal or Metrodin, Serono Laboratories, Norwell, MA, USA; Humegon, Organon, West Orange, NJ, USA) while maintained on leuprolide acetate treatment. When at least two follicles with diameters $\geqslant 17 \mathrm{~mm}$ and serum estradiol levels of $\geqslant 500 \mathrm{pg} / \mathrm{ml}$ were noted, patients were treated with $10000 \mathrm{U}$ of human chorionic gonadotropin (Pregnyl, Organon; Profasi, Serono Laboratories). Preovulatory follicles were aspirated and flushed $35 \mathrm{~h}$ later. Discarded follicular aspirates pooled from several follicles per patient were centrifuged $\left(10 \mathrm{~min}, 700 \times \mathrm{g}, 20^{\circ} \mathrm{C}\right)$, and the top layer of cells enriched with GLC was carefully collected into Ham's F-10 medium (supplemented as described in Piquette et al, 1994). Following a second centrifugation step, the top GLC-enriched cell layer was collected in Ham's F-10 medium and then centrifuged through 50\% Percoll (prepared in Ham's F-10 medium) for 30 min at $700 \times g$. Following Percoll separation, the GLC-enriched interphase layer was collected, washed in Ham's F-10 medium and centrifuged once again. The resultant GLC pellet was snap-frozen and stored at $-80^{\circ} \mathrm{C}$ until RNA extraction and analysis.
Baboon ovaries As a comparative model system, ovaries were collected from normal-cycling adult female baboons (Papio anubis) weighing between $12-16 \mathrm{~kg}$. Animals were housed individually in large aluminium/stainless steel primate cages in air-conditioned rooms with a $12 \mathrm{~h}$ light: $12 \mathrm{~h}$ dark cycle. Baboons received high-protein monkey chow (Purina Mills, St. Louis, MO, USA) twice daily, fresh fruit and vitamins once daily, and water ad libitum. Menstrual cycles were monitored by records of cycle history and by turgescence of external sex skin (Albrecht, 1980). Ovaries were surgically removed from baboons anesthetized with a mixed gas of halothane $(1-1.5 \%)$ : nitrous oxide ( 0.5 liters $/ \mathrm{min})$ : oxygen (2 liters $/ \mathrm{min})$. Depending upon the experiment, ovaries were either fixed immediately in $4 \%$ neutralbuffered paraformaldehyde ( $n=4$ animals; in situ DNA labeling analysis) or were used for microdissection of individual follicles under a stereomicroscope ( $n=2$ animals; biochemical analysis of DNA for internucleosomal cleavage). In the latter instance, isolated follicles obtained from late ovulatory phase ovaries were sized, snap-frozen in liquid nitrogen, and stored at $-80^{\circ} \mathrm{C}$ until processed for DNA analysis. Dominant versus subordinate follicles were selected based on size, with the largest diameter follicle obtained from the late follicular phase ovaries in each animal designated as dominant.

Protocols All protocols involving human and baboon tissue collection were reviewed and approved by the appropriate institutional review committees (IRB/HSPC and IACUC). Studies with baboons were conducted in strict accordance with United States Department of Agriculture (USDA) regulations and with the protocols set forth in the $\mathrm{NIH}$ Guide for the Care and Use of Laboratory Animals (publication 8523, 1985).

\section{In situ labeling for apoptosis}

Localization of apoptosis-associated DNA strand breaks in fixed ovarian tissue sections was performed using a non-radioactive DNA labeling technique, as previously described in detail (Tilly, 1994). Briefly, tissues were fixed in $4 \%$ neutral-buffered paraformaldehyde for $24 \mathrm{~h}$, washed in sterile 7\% sucrose (w:v in $1 \times$-concentrated D-PBS), embedded in paraffin, and sectioned $(6 \mu \mathrm{m})$ for mounting on 3aminopropyltriethoxysilane (AES, Aldrich Chemical, Milwaukee, WI, USA)-coated glass slides. Sections were treated for $30 \mathrm{~min}$ with $10 \mu \mathrm{g} /$ $\mathrm{ml}$ proteinase-K (Boehringer-Mannheim, Indianapolis, IN, USA) to release intercalated proteins from the DNA, washed and labeled for 15 min with biotin-14-deoxy-ATP (dATP; Grand Island, NY, USA) using terminal transferase enzyme (Boehringer-Mannheim). Sites of incorporation of biotinylated-dATP were detected using streptavidinalkaline phosphatase (Sigma Chemical Co., St. Louis, MO, USA) with nitroblue tetrazolium salt (NBT; $300 \mu \mathrm{g} / \mathrm{ml}$ ) and 5-bromo-4-chlor-3indolylphosphate toluidinium salt (BCIP; $248 \mu \mathrm{g} / \mathrm{ml}$ ) as colorimetric substrates for the reaction. Negative controls included processing of samples in the absence of terminal transferase enzyme or the labeling nucleotide. In either case, no colorimetric reaction was observed (data not shown).

\section{Biochemical analysis of DNA oligonucleosomes}

Genomic DNA was extracted from individual follicles as originally described (Gross-Bellard et al, 1973) and modified (Tilly and Hsueh, 1993). The quantity and purity of each nucleic acid sample was assessed by measuring the optical density at A260 nm versus A280 nm. Purity estimates for each sample, as measured by the ratio of $A 260: A 280$, were consistently 1.85 or greater. An equivalent amount of DNA $(500 \mathrm{ng})$ from each sample was then labeled in parallel on $3^{\prime}$-ends with $\left[\alpha^{32} \mathrm{P}\right.$ ]-dideoxy-ATP (ddATP; $3000 \mathrm{Ci} / \mathrm{mmol}$; Amer- 
sham, Arlington Heights, IL, USA) using terminal transferase enzyme (Boehringer-Mannheim), as detailed previously (Tilly and Hsueh, 1993; Tilly, 1994). For qualitative assessments of DNA integrity (the absence or presence of DNA oligonucleosomes characteristic of apoptosis), labeled samples were analyzed by autoradiography (Hyperfilm, Amersham) at $-80^{\circ} \mathrm{C}$ following size fractionation through $2 \%$ agarose gels (Tilly, 1994).

\section{Extraction of RNA}

Total RNA was extracted and purified using the guanidinium thiocyanate-phenol-chloroform single-step procedure, as described (Chomczynski and Sacchi, 1987). The quantity and purity of each nucleic acid sample was assessed by measuring the optical density at A260 $\mathrm{nm}$ versus A280 $\mathrm{nm}$.

\section{Isolation and characterization of human cDNAs}

Total RNA isolated from human ovarian tissue was reverse transcribed into first strand cDNA using random hexamer primers (Boehringer Mannheim) and avian myeloblastosis virus reverse transcriptase (AMV-RT) (Promega, Madison, WI, USA). After computer analysis of appropriate CDNA sequences using the OLIGO program, primers were synthesized (DNA International, Lake Oswego, OR, USA) based on human bcl-2 (forward: 5'-TAT-AAG-CTG-TCG-CAG-AGG-GG-3', bases 61 through 80; reverse: 5'-TGA-CGC-TCT-CCA-CAC-ACATG-3', bases 490 through 471; Cleary et al, 1986), bcl-x/ong (forward: 5'-TTG-GAC-AAT-GGA-CTG-GTT-GA-3', bases -39 through -20 of the $5^{\prime}$-untranslated region; reverse: 5'-GTA-GAG-TGG-ATG-GTCAGT-G-3', bases 6 through 24 of the $3^{\prime}$-untranslated region; Boise et al, 1993), bax (forward: 5'-GGT-TTC-ATC-CAG-GAT-CGA-GAC-GG$3^{\prime}$, bases 85 through 106; reverse: 5'-ACA-AAG-ATG-GTC-ACG-GTCTGC-C-3', bases 530 through 509; Oltvai et al, 1993), p53 (forward: 5'TGC-GTG-TGG-AGT-ATT-TGG-ATG-AC-3', bases 206 through 228; reverse: 5'-ACT-GAC-CCT-TTT-TGG-ACT-TCA-GG-3', bases 730 through 708; Matlashewski et al, 1984), caspase-1/lce (forward: 5'TGC-CCA-GAG-CAC-AAG-ACT-TCT-GAC-3', bases 660 through 683; reverse: 5'-CGA-ACC-TTT-CTG-AAA-ATG-TCC-TCC-3', bases 1117 through 1094; Cerretti et al, 1992), caspase-2/lch-1 (forward: 5'TGG-CAT-ATA-GGT-TGC-AGT-CTC-GG-3', bases 518 through 540; reverse: $5^{\prime}$-TGT-TCT-GTA-GGC-TTG-GGC-AGT-TG-3', bases 880 through 858; Wang et al, 1994) or caspase-3/CPP32 (forward: 5'ACA-TGG-AAG-CGA-ATC-AAT-GGA-CTC-3', bases 287 through 301; reverse: 5'-AAG-GAC-TCA-AAT-TCT-GTT-GCC-ACC-3', bases 973 through 950; Fernandes-Alnemri et al, 1994) mRNA coding sequences, and were used for polymerase chain reaction (PCR) amplification of the corresponding human cDNA sequences as follows. The first strand CDNA was subjected to 35 cycles of PCR amplification using one of the primer sets $\left(1 \mathrm{~min}\right.$ denaturation at $94^{\circ} \mathrm{C}, 1 \mathrm{~min}$ annealing at $50^{\circ} \mathrm{C}$, and 2 min extension at $72^{\circ} \mathrm{C}$ ). The amplified products were resolved through $1.5 \%$ agarose gels, isolated, purified (Gene Clean; Bio 101, La Jolla, CA, USA) and subcloned into the pCRII vector (Invitrogen, San Diego, CA, USA) for large-scale plasmid preparation and automated DNA sequence analysis (version 2.0.15; Applied Biosystems, Foster City, CA, USA).

\section{Preparation of radiolabeled probes and Northern blot analysis}

We were not successful in the isolation of a $b c l-2$ cDNA from human ovarian RNA by RT-PCR amplification; however, all other CDNA sequences were isolated. Antisense RNA probes complementary to human $b c l-x$, bax, p53, caspase-1, caspase-2 and caspase-3 mRNA coding sequences were synthesized by in vitro transcription from linearized plasmid templates using RNA polymerase, $\left[\alpha^{32} \mathrm{P}\right]-\mathrm{CTP}$ (3000 Ci/mmol; Amersham) and the Gemini II Riboprobe Core System (Promega), as described (Melton et al, 1984). For the Southern blot hybridization analysis, the human $b c l-x$ cDNA probe was radiolabeled with $\left[\alpha^{32} \mathrm{P}\right]$-deoxy-CTP (3000 Ci/mmol; Amersham) using the random priming method (Feinberg and Vogelstein, 1983), and purified from unincorporated radionucleotides by column chromatography (NucTrap Push Columns, Stratagene, La Jolla, CA, USA).

Total RNA samples prepared from human ovarian tissues or from Percoll-purified human GLC were fractionated through 1.2\% denaturing agarose gels ( $10 \mu \mathrm{g}$ RNA/lane), visualized with ethidium bromide staining and UV transillumination (to confirm RNA integrity and sample loading equality), and blotted to pure nitrocellulose membranes (Schleicher and Schuell, Keene, NH, USA) by overnight capillary transfer using $20 \times$-concentrated sodium chloride/sodium citrate solution ( $20 \times$-concentrated SSC: $3 \mathrm{M}$ sodium chloride, $0.3 \mathrm{M}$ sodium citrate) as the transfer buffer. The RNA samples were then UV cross-linked to the membranes (Stratalinker, Promega), and hybridized to radiolabeled antisense RNA probes $\left(3 \times 10^{6} \mathrm{cpm} / \mathrm{ml}\right.$ hybridization buffer) under highly stringent conditions at $65^{\circ} \mathrm{C}$ for $18-$ $20 \mathrm{~h}$, as described (Tilly et al, 1995a,b; Flaws et al, 1995). Following a 10 min wash at $20^{\circ} \mathrm{C}$ in $2 \times$-concentrated SSC $/ 0.1 \%$ sodium dodecyl sulfate (SDS) and extensive washing $(20-40 \mathrm{~min})$ at $65^{\circ} \mathrm{C}$ in $0.1 \mathrm{x}$ concentrated SSC $/ 0.1 \%$ SDS, autoradiography was carried out by exposure of membranes to film (Hyperfilm, Amersham) for 2-8 days at $-80^{\circ} \mathrm{C}$.

\section{RT-PCR/Southern blot analysis of alternatively- spliced bcl-x transcripts}

To determine the relative expression of the 'long' (death repressor) versus 'short' (death inducer) forms of bcl-x mRNA (Boise et al, 1993), total RNA samples prepared from human ovarian tissue or from Percoll-purified human GLC were subjected to RT-PCR analysis using human $b c l-x$ primers (see 'Isolation and Characterization of Human cDNAs' above) that span the $189 \mathrm{bp}$ region deleted in $b c /-x_{\text {short }}$ (Tilly et al, 1995a). Following a 25-cycle amplification, one-tenth of the resultant PCR reaction containing the amplified CDNA products was resolved by gel electrophoresis and blotted to nylon-reinforced nitrocellulose membranes (Schleicher and Schuell) by overnight capillary transfer using $10 \times$-concentrated SSC. Southern blot hybridization was then conducted with a radiolabeled human $b c l-x$ cDNA probe at $42^{\circ} \mathrm{C}$ for $18-20 \mathrm{~h}$ (Tilly et al, 1995a), after which membranes were washed under highly stringent conditions (see above). Autoradiography was then carried out by exposure of blots to film (Hyperfilm, Amesham) for 2-18 $\mathrm{h}$ at $-70^{\circ} \mathrm{C}$. Identity of the two amplified PCR products was further confirmed by sequence analysis.

\section{Immunohistochemistry}

Paraffin-embedded fixed human ovarian tissue sections, mounted on glass slides as described above (see 'In Situ DNA Labeling Analysis' above), were subjected to immunohistochemical staining for the presence and distribution of the BAX death-susceptibility protein using a rabbit polyclonal antiserum raised against a human BAX peptide sequence, as detailed previously (Krajewski et al, 1994). Briefly, high temperature antigen unmasking was first performed by microwaving the sections for $5.5 \mathrm{~min}$ in $10 \mathrm{mM}$ sodium citrate. After cooling, sections were treated with $0.5 \%$ hydrogen peroxide (in methanol) for $5 \mathrm{~min}$ at $20^{\circ} \mathrm{C}$ to quench endogenous peroxidase activity, pre-blocked with TNK buffer 
(100 mM Tris- $\mathrm{HCl}(\mathrm{pH} 7.6), 550 \mathrm{mM} \mathrm{NaCl}, 10 \mathrm{mM} \mathrm{KCl}, 2 \%$ bovine serum albumin, $0.1 \%$ Triton $\mathrm{X}-100,1 \%$ normal goat serum) for $45 \mathrm{~min}$ at $20^{\circ} \mathrm{C}$, and then incubated for $18 \mathrm{~h}$ at $4^{\circ} \mathrm{C}$ with the primary antibody diluted 1:500 in TNK buffer, After washing, sections were incubated with a biotinylated goat anti-rabbit lgG $(2.8 \mu \mathrm{g} / \mathrm{ml})$ for $1 \mathrm{~h}$ at $20^{\circ} \mathrm{C}$, and then washed again. Localization of the primary antibody-biotinylated second antibody complex was then performed using streptavidin-horseradish peroxidase with diaminobenzadine as the chromogenic substrate (Krajewski et al, 1994). To permit visualization of the tissue architecture, slides were lightly counterstained with hematoxylin before coverslipping. As negative controls, sections were prepared and analyzed as described with primary antibody replaced by normal rabbit serum. Under these conditions, no immunoreaction was observed (data not shown).

\section{Data analysis and presentation}

For studies of human ovaries and GLC, all experiments were repeated with tissues or cells collected from at least five or ten different patients, respectively. Comparative studies conducted with baboon ovarian tissues were done with four different animals, with the exception that the dissection and analysis of apoptosis in dominant versus subordinate follicles was conducted with ovaries from two different animals in the ovulatory phase of the cycle. For all studies, photomicrographs (in situ DNA analysis, immunohistochemistry) and autoradiograms (biochemical DNA analysis, Northern and Southern blot analyses) representative of results obtained with different patient or baboon samples are provided (see also Figure Legends).

\section{Acknowledgements}

A portion of the studies described herein were initiated while KK, VSR, KIT, SM and JLT were at Johns Hopkins University (Baltimore, MD, USA). This study was supported by NIH Grants R01-AG12279 (JLT), R55HD31188 (JLT), R01-HD34226 (JLT), R01-HD13294 (EDA and GJP), and by grants from the American Federation for Aging Research (JLT), the NIH Office of Research on Women's Health (JLT) and IVF America (JLT). KK is on leave from the Department of Obstetrics and Gynecology, The University of Tokyo, Faculty of Medicine, Tokyo 113, Japan. VSR is a recipient of a North American Menopause Society/Wyeth-Ayerst Research Grant Award.

\section{References}

Albrecht ED (1980) A role for estrogen in progesterone production during baboon pregnancy. Am. J. Obstet. Gynecol. 136: 569-574

Boise LH, Gonzalez-Garcia M, Postema CE, Ding L, Lindsten T, Turka LA, Mao X, Nuñez $G$ and Thompson CB (1993) $b c l-x$, a $b c l-2-$ related gene that functions as a dominant regulator of apoptotic cell death. Cell 74: 597-608

Cerretti DP, Kozlozky CJ, Mosley B, Nelson N, Van Ness K, Greenstreet TA, March CJ, Kronheim SR, Druck T, Cannizzaro LA, Huebner K and Black RA (1992) Molecular cloning of the interleukin-1-beta converting enzyme. Science 256: $97-100$

Chinnaiyan AM, Orth K, O'Rourke K, Duan H, Poirier GG and Dixit VM (1996) Molecular ordering of the cell death pathway. BCL-2 and BCL-X function upstream of the CED-3-like apoptotic proteases. J. Biol. Chem. 271:4573-4576

Chomczynski P and Sacchi N (1987) Single-step method of RNA isolation by acid guanidinium thiocyanate-phenol-chloroform extraction. Anal. Biochem. 162: $156-159$

Cleary ML, Smith SD and Sklar J (1986) Cloning and structural analysis of cDNAs for $b c l-2$ and a hybrid $b c l-2 /$ immunoglobulin transcript resulting from the $t(14 ; 18)$ translocation. Cell 47: 19-28
Dharmarajan AM, Goodman SB, Tilly KI and Tilly JL (1994) Apoptosis during functional corpus luteum regression: evidence of a role for chorionic gonadotropin in promoting luteal cell survival. Endocr. J. (Endocrine) 2: 295303

Estoppey S, Rodriquez I, Sadoul Rand Martinou J-C (1997)Bcl-2 prevents activation of CPP32 cysteine protease and cleavage of poly (ADP-ribose) polymerase and U1-70 kD proteins in staurosporine-mediated apoptosis. Cell Death Differ. 4: $34-38$

Feinberg AP and Vogelstein B (1983) A technique for radiolabeling DNA restriction endonuclease fragments to high specific activity. Anal. Biochem. 132: 6-13

Fernandes-Alnemri T, Litwack G and Alnemri ES (1994) CPP32, a novel human apoptotic protein with homology to Caenorhabditis elegans cell death protein CED-3 and mammalian interleukin-1 $\beta$-converting enzyme. J. Biol. Chem. 269: 30761-30764

Flaws JA, Kugu K, Trbovich AM, Tilly KI, DeSanti A, Hirshfield AN and Tilly JL (1995) Interleukin-1 $\beta$-converting enzyme-related proteases (IRPs) and mammalian cell death: dissociation of IRP-induced oligonucleosomal endonuclease activity from morphological apoptosis in granulosa cells of the ovarian follicle. Endocrinology 136: $5042-5053$

Gavrieli Y, Sherman Y and Ben-Sasson A (1992) Identification of programmed cell death in situvia specific labeling of nuclear DNA fragmentation. J. Cell. Biol. 119: 493-501

Gross-Bellard M, Oudet P and Chambon P (1973) Isolation of high-molecular-weight DNA from mammalian cells. Eur. J. Biochem. 36: 32-38

Hughes Jr FM and Gorospe WC (1991) Biochemical identification of apoptosis (programmed cell death) in granulosa cells: evidence for a potential mechanism underlying follicular atresia. Endocrinology 129: 2415-2422

Johnson AL, Bridgham JT, Witty JP and Tilly JL (1996) Susceptibility of avian ovarian granulosa cells to apoptosis is dependent upon stage of follicle development and is related to endogenous levels of $b c l-x_{\text {long }}$ gene expression. Endocrinology 137: 2059-2066

Johnson AL, Bridgham JT, Witty JP and Tilly JL (1997) Expression of $b c l-2$ and NR13 in hen ovarian follicles during development. Biol. Reprod. 57: (In Press)

Jolly PD, Tisdall TJ, Heath DA, Kun S and McNatty KP (1994) Apoptosis in bovine granulosa cells in relation to steroid synthesis, cyclic adenosine $3^{\prime}, 5^{\prime}$ monophosphate response to follicle-stimulating hormone and luteinizing hormone, and follicular atresia . Biol. Reprod. 51: 934-944

Jolly PD, Tisdall DJ, De'ath G, Heath DA, Lun S, Hudson NL and McNatty KP (1997) Granulosa cell apoptosis, aromatase activity, cyclic adenosine $3^{\prime} 5^{\prime}$-monophosphate response to gonadotropins, and follicular fluid steroid levels during spontaneous and induced follicular atresia in ewes. Biol. Reprod. 56: 830-836

Keren-Tal I, Suh B-S, Dantes A, Lindner S, Oren M and Amsterdam A (1995) Involvement of p53 expression in cAMP-mediated apoptosis in immortalized cells. Exp. Cell. Res. 218: 283-295

Knudson CM, Tung KSK, Tourtellotte WG, Brown GAJ and Korsmeyer SJ (1995) Baxdeficient mice with lymphoid hyperplasia and male germ cell death. Science 270: $96-99$

Ko LJ and Prives C (1996) p53: puzzle and paradigm. Genes Devlop. 10: 1054-1072

Krajewski S, Krajewska M, Shabaik A, Miyashita T, Wang H-G and Reed JC (1994) Immunohistochemical determination of in vivo distribution of Bax, a dominant inhibitor of Bcl-2. Am. J. Pathol. 145: 1323-1336

KumarS (1997) The Bcl-2 family of proteins and activation of the ICE-CED-3 family of proteases: a balancing act in apoptosis? Cell Death Differ. $4: 2-3$

Kumar S and Lavin MF (1996) The ICE family of cysteine proteases as effectors of cell death. Cell Death Differ. 3: 255-267

Lu Q-L, Poulson R, Wong L and Hanby AM (1993) Bcl-2 expression in adult and embryonic non-haematopoietic tissues. J. Pathol. 169: 431-437

Maravei DV, Trbovich AM, Perez Gl, Tilly KI, Talanian RV, Banach D, Wong WW and Tilly JL (1997) Cleavage of cytoskeletal proteins by caspases during ovarian cell death: evidence that cell-free systems do not always mimic apoptotic events in intact cells. Cell Death Differ. 4: 707-712

Martimbeau S and Tilly JL (1997) Physiological cell death in endocrine-dependent tissues: an ovarian perspective. Clin. Endocrinol. 46: 241-254

Martin SJ and Green DR (1995) Protease activation during apoptosis: death by a thousand cuts? Cell 82: $349-352$

Matlashewski G, Lamb P, Pim D, Peacock J, Crawford L and Benchimol S (1984) Isolation and characterization of a human p53 cDNA clone: expression of the human p53 gene. EMBO J. 3: 3257-3262 
Melton DA, Krieg PA, Rebagliati MR, Maniatis T, Zinn K and Green MR (1984) Efficient in vitro synthesis of bioactive RNA and RNA hybridization probes from plasmids containing a bacteriophage SP6 promoter. Nucl. Acids. Res. 12 $7035-7056$

Miyashita T and Reeed JC (1995) Tumor suppressor p53 is a direct transcriptional activator of the human bax gene. Cell 80: 293-299

Miyashita T, Harigai M, Hanada M and Reed JC (1994) Identification of a p53dependent negative response element in the $b c l-2$ gene. Cancer Res. 54: $3131-3135$

Oltvai ZN, Milliman CL and Korsmeyer SJ (1993) Bcl-2 heterodimerizes in vivo with a conserved homolog, Bax, that accelerates programmed cell death. Cell 74:609-619

Patel T, Gores GJ and Kaufmann SH (1996) The role of proteases during apoptosis. FASEB J. 10: $587-597$

Perez GI, Knudson CM, Leykin L, Korsmeyer SJ and Tilly JL (1997) Apoptosisassociated signaling pathways are required for chemotherapy-mediated female germ cell destruction. Nature Med. (In Press)

Perry DK, Smyth MJ, Wang H-G, Reed JC, Poirier GG, Obeid LM and Hannun YA (1997) Bcl-2 acts upstream of the PARP proteases and prevents its activation. Cell Death Differ. 4: 29-33

Piquette GN, Tilly JL, Prichard L, Simon C and Polan ML (1994) Detection of apoptosis in human and rat ovarian follicles. J. Soc. Gynecol. Invest. 1:297-301

Ratts VS, Flaws JA, Kolp R, Sorenson CM and Tilly JL (1995) Ablation of bcl-2 gene expression decreases the numbers of oocytes and primordial follicles established in the post-natal female mouse gonad. Endocrinology 136: $3665-3668$

Reed JC, Miyashita T, Takayama S, Wang HG, Sato T, Krajewski S, Aimé-Sempé C, Bodrug S, Kitada S and Hanada M (1996) BLC-2 family proteins: regulators of cell death involved in the pathogenesis of cancer and resistance to chemotherapy. J. Cell. Biochem. 60: 23-32

Rodger FE, Fraser HM, Duncan WC and Illingworth PJ (1995) Immunolocalization of $\mathrm{Bcl}-2$ in the human corpus luteum. Human. Reprod. 10: 1566-1570

Rueda BR, Tilly KI, Botros I, Jolly PD, Hansen TR, Hoyer PB and Tilly JL (1997) Increased bax and interleukin-1 $\beta$-converting enzyme (Ice) messenger RNA levels coincide with apoptosis in the bovine corpus luteum during structural regression. Biol. Reprod. 56: 186-193

StellarH (1995) Mechanisms and genes of cellular suicide. Science 267: 1445-1449

Tao X-J, Tilly KI, Maravei DV, Shifren JL, Krawjewski S, Reed JC, Tilly JL and Isaacson KB (1997) Differential expression of members of the $b c l$-2 gene family in proliferative and secretory human endometrium: glandular epithelial cell apoptosis is associated with increased expression of bax. J. Clin. Endocrinol. Metab. 82: 2738-2746
Tilly JL (1993) Ovarian follicular atresia: a model to study the mechanisms of physiological cell death. Endocr. J. (Endocrine) 1:67-72

Tilly JL (1994) Use of the terminal transferase DNA labeling reaction for the biochemical and in situ analysis of apoptosis. In Cell Biology: a laboratory handbook, in Celis JE, ed. (San Diego: Academic Press) pp. 330-337

Tilly JL (1996) Apoptosis and ovarian function. Rev. Reprod. 1: 162-172

Tilly JL and Hsueh AJW (1993) Microscale autoradiographic method for the qualitative and quantitative analysis of apoptotic DNA fragmentation. J. Cell. Physiol. 154: 519-526

Tilly JL and Perez GI (1997) Mechanisms and genes of physiological cell death: a new direction for toxicological risk assessments? In Comprehensive toxicology, in Sipes IG, McQueen CA and Gandolfi AJ, eds. (Oxford: Elsevier Press) 10: 379 385

Tilly JL and Ratts VS (1996) Biological and clinical importance of ovarian cell death. Contemp. Obstet. Gynecol. 41: 59-86

Tilly JL, Kowalski KI, Johnson AL and Hsueh AJW (1991) Involvement of apoptosis in ovarian follicular atresia and postovulatory regression. Endocrinology 129: 2799-2801

Tilly JL, Kowalski KI, Schomberg DW and Hsueh AJW (1992) Apoptosis in atretic ovarian follicles is associated with selective decreases in messenger ribonucleic acid transcripts for gonadotropin receptors and cytochrome P450 aromatase. Endocrinology 131: 1670-1676

Tilly JL, Tilly KI, Kenton ML and Johnson AL (1995a) Expression of members of the $b c l-2$ gene family in the immature rat ovary: equine chorionic gonadotropinmediated inhibition of apoptosis is associated with decreased bax and constitutive $b c l-2$ and $b c /-x_{\text {long }}$ messenger ribonucleic acid levels. Endocrinology 136: $232-241$

Tilly KI, Banerjee S, Banerjee PP and Tilly JL (1995b) Expression of the p53 and Wilm's tumor suppressor genes in the rat ovary: gonadotropin repression in vivo and immunohistochemical localization of nuclear p53 protein to apoptotic granulosa cells of atretic follicles. Endocrinology 136: 1394-1402

Tilly JL, Tilly KI and Perez GI (1997) The genes of cell death and cellular susceptibility to apoptosis in the ovary: a hypothesis. Cell Death Differ. 4: 180-187

Wang L, Miura M, Bergeron L, Zhu H and Yuan J (1994) Ich-1, an Ice/ced-3-related gene, encodes both positive and negative regulators of programmed cell death. Cell 78: $739-750$

Wyllie AH (1995) The genetic regulation of apoptosis. Curr. Opin. Genet. Develop. 5: 97-104

Yang E and Korsmeyer SJ (1996) Molecular thanatopsis: a discourse on the BCL-2 family and cell death. Blood 88: 386-401 